\begin{tabular}{|c|l|}
\hline Title & $\begin{array}{l}\text { Large deletion of androsterone UDP-glucuronosyltransferase gene in the inherited deficient } \\
\text { strain of wistar rats }\end{array}$ \\
\hline Sub Title & \\
\hline Author & $\begin{array}{l}\text { 本間, 浩(Honma, Hiroshi) } \\
\text { 川合, 博幸(Kawai, Hiroyuki) } \\
\text { 保田, 三保(Kubota, Miho) } \\
\text { 松井, 道夫(Matsui, Michio) }\end{array}$ \\
\hline Publisher & 共立薬科大学 \\
\hline Publication year & 1992 \\
\hline Jtitle & $\begin{array}{l}\text { 共立薬科大学研究年報 (The annual report of the Kyoritsu College of } \\
\text { Pharmacy). No.37 (1992.),p.71- 71 }\end{array}$ \\
\hline JaLC DOI & \\
\hline Abstract & \\
\hline Notes & 抄録 \\
\hline Genre & Technical Report \\
\hline URL & $\begin{array}{l}\text { https://koara.lib.keio.ac.jp/xoonips/modules/xoonips/detail.php?koara_id=AN00062898-0000003 } \\
7-0071\end{array}$ \\
\hline
\end{tabular}

慶應義塾大学学術情報リポジトリ(KOARA)に掲載されているコンテンツの著作権は、それぞれの著作者、学会または出版社/発行者に帰属し、その権利は著作権法によって 保護されています。引用にあたっては、著作権法を遵守してご利用ください。

The copyrights of content available on the KeiO Associated Repository of Academic resources (KOARA) belong to the respective authors, academic societies, or publishers/issuers, and these rights are protected by the Japanese Copyright Act. When quoting the content, please follow the Japanese copyright act. 


\title{
Large deletion of androsterone UDP-glucuronosyltransferase gene in the inherited deficient strain of Wistar rats*
}

\author{
Hiroshi Homma, Hiroyuki KawaI, Miho Kubota \\ and Michio MatsuI
}

本間 浩, 川合博幸, 久保田三保, 松井道夫

LA Wistar rats have a deficiency of androsterone UDP-glucuronosyltransferase (UDPGT) and are present in Wistar rat colonies around the world. In order to clarify the molecular mechanism of the deficiency, androsterone UDPGT cDNA clone, pGT2 was isolated from rat liver cDNA library and was digested with restriction enzymes to afford 3 probes for Northern and Southern blot analyses in HA (normal), heterozygous LA and LA Wistar rats. In Northern blot analysis, androsterone UDPGT mRNA was totally absent in LA wistar rat liver. Southern blot analysis suggested a large deletion of androsterone UDPGT gene in the rats. Genomic DNA amplifications with synthetic primers which have nucleotide sequences corresponding to the 5 '-region of androsterone UDPGT cDNA, suggested that androsterone UDPGT gene has exon I with a length of some $700 \mathrm{bp}$ and that this exon is deleted in LA Wistar rats. Based on these lines of evidence, it is concluded that the large portion of androsterone UDPGT gene is deleted in LA Wistar rats, which results in the absence of androsterone UDPGT mRNA and consequently the corresponding enzyme protein.

* 本報告は Biochim. Biophys. Acta., 1138, 34-40（1992）に発表. 